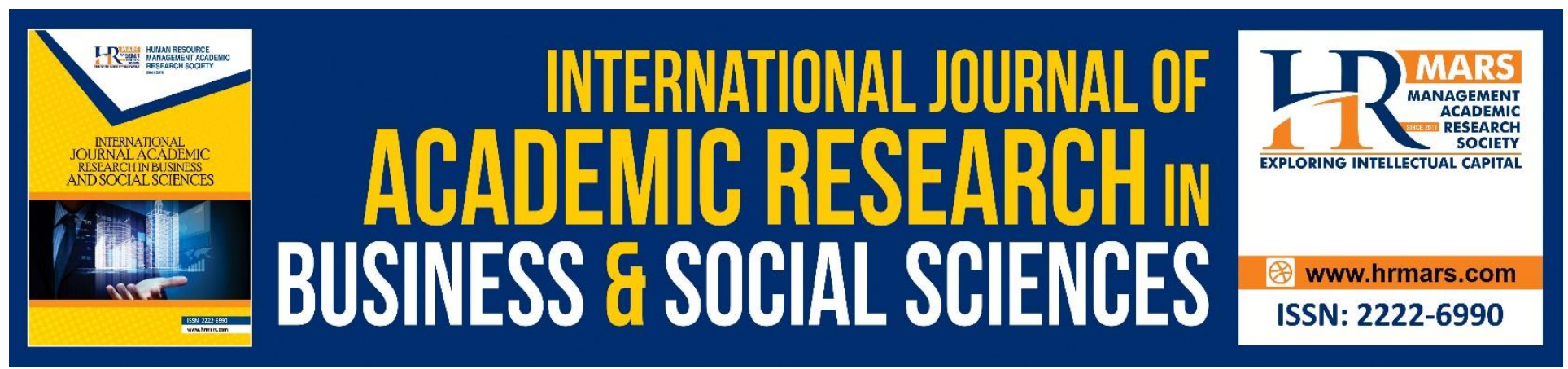

\title{
Attitude and Self-efficacy and its Relationships with Entrepreneur Intention Among Undergraduate Students
}

\section{Azyyati Zakaria and Norshidah Mohamed Nordin}

To Link this Article: http://dx.doi.org/10.6007/IJARBSS/v10-i14/7684

Received: 09 April 2020, Revised: 10 May 2020, Accepted: 05 June 2020
DOI:10.6007/IJARBSS/v10-i14/7684

Published Online: 26 July 2020

In-Text Citation: (Zakaria \& Nordin, 2020)

To Cite this Article: Zakaria, A., \& Nordin, N. M. (2020). Attitude and Self-efficacy and its Relationships with Entrepreneur Intention Among Undergraduate Students. International Journal of Academic Research in Business and Social Sciences, 10(14), 145-158.

Copyright: (C) 2020 The Author(s)

Published by Human Resource Management Academic Research Society (www.hrmars.com)

This article is published under the Creative Commons Attribution (CC BY 4.0) license. Anyone may reproduce, distribute, translate and create derivative works of this article (for both commercial and non-commercial purposes), subject to full attribution to the original publication and authors. The full terms of this license may be seen at: http://creativecommons.org/licences/by/4.0/legalcode

Special Issue: WSTI2018 - Issues and Trends on Education, Science and Technology, 2020, Pg. 145 - 158 http://hrmars.com/index.php/pages/detail/IJARBSS

Full Terms \& Conditions of access and use can be found at http://hrmars.com/index.php/pages/detail/publication-ethics 


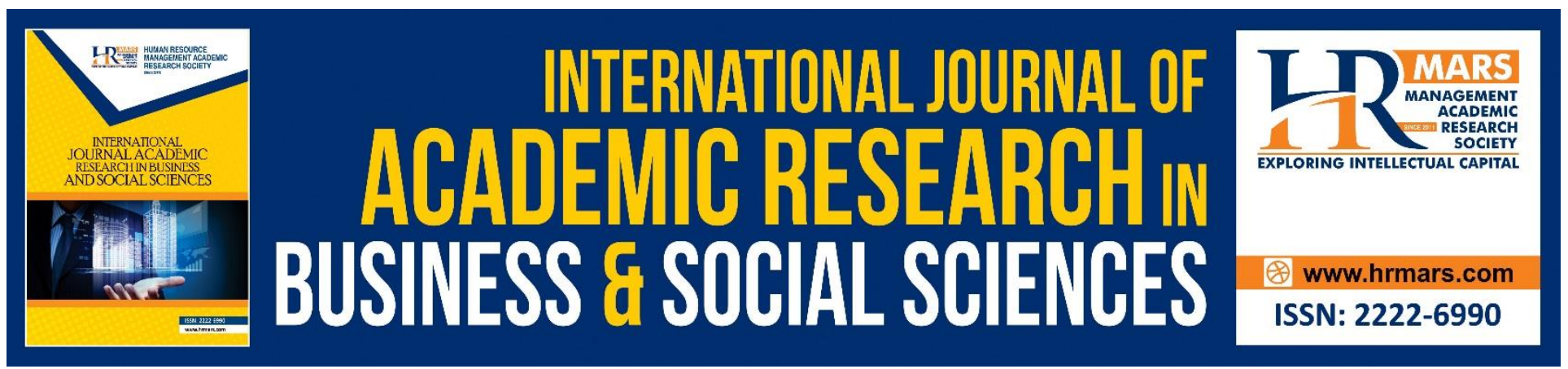

\title{
Attitude and Self-efficacy and its Relationships with Entrepreneur Intention Among Undergraduate Students
}

\author{
Azyyati Zakaria ${ }^{1}$ and Norshidah Mohamed Nordin² \\ Faculty of Education, UiTM, Malaysia \\ Email: ${ }^{1}$ azyzakaria105@gmail.com, ${ }^{2}$ shidah147@gmail.com
}

\begin{abstract}
Nurturing entrepreneurship among universities students have become vital concerned for current education policy of Malaysia. Studies depicted that university students' career ambition to entrepreneur intention is on the rise. This study was intended to examine the influence of self efficacy and attitude on entrepreneurship intention among university students. 181 students from the faculty of Education participated in this study. The finding showed positive and moderate relationship between entrepreneur attitude, subjective norms and self-efficacy on entrepreneur intentions. This study suggests universities played important roles in developing the environment of the entrepreneurship for future growth and sustainability.
\end{abstract}

Keywords: Entrepreneur Intention, Entrepreneurship, Self-efficacy, Attitude.

\section{Introduction}

Entrepreneurship has become a main agenda for the Malaysian government in its quest to become an entrepreneurial nation. Many studies showed that there is a linked between entrepreneurship education and the development of entrepreneurship (Solomon et al., 2002; Katz, 2003). Hence, entrepreneurial education has been given important agenda in cultivating entrepreneurial culture especially among the university students (Rahim \& Mohtar, 2015). In this sense, much efforts have been done to boost entrepreneurship development in the country such as setting up 1Malaysia Entrepreneur program, National Entrepreneurship Institute and Malaysian Global Innovation Creativity Centre. Apart from that, universities and colleges were given special tasks in educating the entrepreneur interest among university students and graduates. In fact, entrepreneurship has been taught as one of the subjects in most universities and students are also encouraged to participate in entrepreneurship activities such as trainings, seminars, short courses, conferences and entrepreneurship events (Rahim \& Mohtar, 2015). Entrepreneurship activities are also evaluated in the students' integrated cumulative grade point average (iCGPA)

Apparently, graduates are seeking to venture into entrepreneurship due less job opportunities in the market. It was reported in the Malaysian Department of Statistical that the 
employment rate have increased drastically since 2015 (Tawil et al, 2015). Parallel, Amouri et. al. (2016) asserted that due to less prospects of being employed and fewer chances for getting salaried in established organizations, individuals seek other alternatives such as being self-employed. Besides, literature found that graduates who inspired to work in a government sector or having salaried employment have no guarantee anymore (Kamau-Maina 2006; Postigo \& lacobucci, 2006). Indeed, studies evident that self-employment has been sought after among graduates (Baughn et. al. 2006). Thus, entrepreneurship has an important opportunity to generate more employment in the market. Several empirical studies supported these findings. For instance, in a study conducted on graduates from university of Pennsylvania, found that more than 7\% of 2013 graduates started their own company after graduation, which is five times as many as in 2007, (Bliemel, 2014). In addition, Charney and Gary (2000) noticed that about $27.2 \%$ of the graduates students who took up entrepreneur education had set up their own businesses. Mohammad et al. (2014) depicted in their studies that about $51.5 \%$ of the students become entrepreneur, that is, five years after they graduated from the university. On the contrary, studies also found that graduate students were not interested in making entrepreneurship as their career or being self-employed. For example, Buang (2013) found that students were more favoured to have salaried job rather than becoming entrepreneurs. In a study done by Bakar et al. (2012) found that there were only $13.1 \%$ of the undergraduate students who involved hem in setting up their own business, six month after they have graduated.

Given this juncture, the above indicators warrant further research as entrepreneurial activities are generally attached to factors such as attitude, motivation, self-efficacy and social supports. Besides, Guyo (2013) noted that providing students with knowledge and skills are not sufficient for students to become entrepreneur. In addition, Tsordia and Papadimitriou (2015) found that entrepreneurial curriculum and content were not significant in influencing the intentions of business students to pursue a self-employed career. Therefore, Ajzen (1991) said that developing entrepreneurship requires conscious planned of behaviour because he claimed that intention of individual precede one's action or behaviour. In other words, these students need to have entrepreneurial intention before they could venture as entrepreneur in the future. This study seeks to examine to what extend undergraduate students from the faculty of Education who were trained to become teacher have the intention to be entrepreneurs and whether these students' attitude, subjective norms and self-efficacy can enhance their intention towards entrepreneurship.

\section{The Concepts and Theory of Entrepreneurial Intention and its Predictors}

Bandura (2001) stated that intention can be described as prospect or action that one would perform in the future. Pihie (2009) described intention as a behaviour that result from attitude and develop into determinant of behaviour. While, entrepreneurship is a process of generating or initiating new business start-up (Hisrich and Peters, 2002). Parallel, Low and MacMillan (1988) defined entrepreneurship as a formation of new enterprise. While, Gartner, Bird and Starr (1992) viewed it as means of organizational emergence. Pihie (2009) noticed that there were two ways to consider entrepreneurship: 1) actual entrepreneurship is referred to as an individual who has already started his/her business; 2) entrepreneurial intention is referred to as an individual who plan or propose to start a business. Krueger et. al. (2000) noted that intentions are deemed as pertinent move in the entrepreneurship process for an individual who wants to venture into new business. Bird (1988) asserted that intentionality is defined as one's conscious state of mind that could direct or 
linked towards achieving specific goals. Therefore, in this sense, people who has the intention to start a new business not only they have tendency or inclination to start but also are rational towards attaining their goals. Thus, Bird (1988) believed that entrepreneurial intention can be furthered explained through cognitive and social psychology theory that endeavour to predict human behaviour. Parallel, Henley (2005) and Fishbein \& Ajzen (1975) asserted that intention is a crucial predictor of subsequent planed behaviour and has drawn attentions to numerous cognitive researches. This study utilized theory of planned behaviour to understand entrepreneurial intentions and its predictors.

Literature review concurred that entrepreneurial intention can be explained from three different perspectives or models (Shook et al, 2003) namely, model of implementing entrepreneurial ideas (Bird,1989); model of the entrepreneurial event (Shapero, 1982); and theory of planned behaviour (Ajzen, 1987). According to Bird (1989), the idea of entrepreneurial intention can be formed when individual's personal (such as personal history, traits and abilities) interact with social contexts (such as individual's social, political and economic). Later, Boyd and Vozikis (1994) further revised Bird's model and added the concept of self-efficacy. They claimed that self-efficacy can be influenced by factors such as social support, role models, and previous career. On the other hand, Shapero (1982) believed that the perception of desirability, feasibility, and a propensity to act upon opportunities are important factors that contributed to entrepreneurial intentions. The model proposed that the inertia will lead human behaviour to some events (e.g. loss of job) that happen to break off the inertia. Thus, this kind of interruption speed up a change in individual's behaviour that makes him/her to search for best opportunities and alternatives available that is based on the perception of desirability and feasibility (Krueger et al. 2000; Shook et al, 2003). Nonetheless, the most popular and widely used to explain entrepreneurial intentions is the theory of planned behaviour (TBP) which was developed by Ajzen (1991).

TPB concurred that much of human behaviour is planned and thus preceded intention. Hence, intention turn out to be the primary factor in explaining the given behaviour. Liñán (2004) suggested that intention is reflected in one's effort that he/she will make to carry out entrepreneurial behaviour. Entrepreneurial intention is basically predicted by cognitive variables or also termed as motivational antecedents such as perceived attitudes, subjective norms and perceived behavioural control. Ajzen (1991) asserted that the more favourable of these three predictors, thus the higher the intentions to perform the particular behaviour. Azjen (2002) noted that perceived attitude is referred to a person's favourable or unfavourable evaluation of the behaviour. Souitaris et al., (2007) said that in this context, attitude towards entrepreneurship can be described as the differences between personel need to become self-employed or the desire to has salaried job. Pulka et al (2014) claimed that there are three components of entrepreneurship attitudes, namely, cognitive, affective and behavioural attitude components. The cognitive aspects, basically, relate to beliefs, thought and knowledge about entrepreneurship and entrepreneurship education that form attitudes and behaviours. While, affective aspects deal with feeling and emotions about entrepreneurship and entrepreneurship education, that is, how an individual perceived the relevance of something and whether individual eventually like or dislike it. Lastly, the behavioural aspect which relates to actions, explicit responses and willingness to respond to or accept something. On the other hand, subjective norms can be referred as perceived social pressure would approve of the decision to become entrepreneur. In this sense, Liñán and Chen (2009) stated that social pressure or reference people such as members of the family, close friends, teachers or even successful entrepreneur seem to play 
important role influencing the decision on one's entrepreneurial intention. Nonetheless, perceived behavioural control is referred as perceptions of easiness or difficulty in accomplishment of becoming an entrepreneur. Liñán and Chen (2009) suggest that the concept perceived behavioural control is quite similar to perceived self-efficacy (Bandura, 1997) and perceived feasibility (Shapero and Sokol, 1982). Bandura (1977) defines self-efficacy as individual belief about his/her ability to achieve certain tasks. De Noble et al (1999) described entrepreneurial self-efficacy as an individual's belief in their abilities to achieve several skills and knowledge in order to take up a new venture opportunity. other authors such as Kumar, (2014); Wilson, Kickul \& Marlino, (2007) and Shane, Lock \& Collins, (2003) concurred that entrepreneurial self-efficacy can be considered motivational factors that stimulates students to decide entrepreneurship as their future career path and willing to face challenges and obstacles that link to new venture opportunities. Hence, students who has high self-efficacy have the tendency to explore entrepreneurial prospect and persistence to achieve their goals (Zhao, Seibert \& Hills, 2005). In this study, perceived behavioural control is measured using the concept of entrepreneurial self-efficacy.

In sum, the central element of TPB is the intention to perform a given behaviour. (in this case intention to become entrepreneur). The stronger the intention to perform the given behaviour the greater probability that the individual tend to venture into entrepreneurial behaviour (Ajzen, 1991). Armitage \& Conner (2001) found that intention accounts for about $30 \%$ of the variance in behaviour. Studies also showed that TPB components such as (attitude, subjective norms and perceived control behaviour) accounted for $21 \%$ (Autio et al, 2001) and 55\% (Linan and Chen, 2009) of the variance in intention. Nevertheless, the results vary according to context of the studies.

\section{Entrepreneur Intention and its Relationship with Attitude, Subjective Norms and Entrepreneurial Self-efficacy}

Studies indicated that the interaction between the components of TPB and entrepreneur have attracted numerous amounts of research. For example, Naina et al (2017) investigated a study of 370 sport sciences undergraduate students in one of the universities in Lisbon, Portugal. They found that perceived attitudes and perceived behaviour control have significant positive impacts on entrepreneurial intentions. On the other hand, there was a negative relationship between subjective norms and entrepreneurial intention. The findings suggested that students who have positive attitude towards entrepreneurship and higher perceived control over their action, will has the tendency to engage themselves with entrepreneurial intentions. The weak and negative impact of subjective norms indicates that a more intense social pressure to the students the less likely the will engage in entrepreneurial intentions. Lame \& Wan Yusoff (2013) in their studies on selected polytechnics students in Nigeria, found that students have low awareness towards the significance of entrepreneurship as their career option. The finding showed that the students' inclination towards entrepreneurship courses was not encouraging. Even though, entrepreneurship courses are compulsory to all public polytechnics in Nigeria, students were favour to work in the government sectors. Conversely, Rudhumbu et al (2016) in their studies found that majority of the students from two private universities in Botswana have a positive attitude towards entrepreneurship education and would prefer to be entrepreneurs at the end of their studies. Parallel, Basu and Virik (2008) evident that entrepreneurship education could enhance attitudes of students towards entrepreneurship. Similarly, Ediagbonya (2013) suggests that developing skills, knowledge and motivation to students may have the positive impacts on the attitudes of students towards 
entrepreneurship. In addition, Solesvik et al. (2012) found that students who have favourable attitude towards self-employment, have the tendency to express their intentions for developing entrepreneurial activities. In terms of subjective norms, the results were not consistent. Some studies showed that there was a significant relationship between subjective norm and entrepreneurial intention (Tkachev \& Kolvereid, 1999; Souitaris et al. (2007). Nevertheless, another research failed to show the relationship between subjective norm with entrepreneurial intention. For example, in a study done by Solesvik et al. (2012) indicated that subjective norms did not correlate with entrepreneurial intentions. Similarly, studies done by Wu \& Wu (2008) and Liñán \& Chen (2006) found that subjective norm does not play a direct role in determining entrepreneurial intention. Another important predictor of entrepreneurial intention is the concepts of self-efficacy. Empirical evidence indicated that entrepreneurial self-efficacy can motivate individual towards entrepreneurial intentions (BarNir, Watson, \& Hutchins (2011); Wilson, Kickul, \& Marlino, 2007). Pihie \& Bagheri (2011) have carried out an investigation to determine entrepreneurial self-efficacy among 315 teachers and 3000 students from technical and vocational school students. Six dimensions of entrepreneurial self-efficacy that include coping with unexpected challenges, developing new products and opportunities, building an innovative environment, initiating investor relationships, defining the core purpose, and developing critical human resources, were measured. The findings showed entrepreneurial self-efficacy was significantly high in all its six dimensions among teachers. However, on the other end, students perceived themselves as moderately high in entrepreneurial self-efficacy. Conversely, Setiawan (2013) conducted a study among undergraduate students using six dimensions of entrepreneurial self-efficacy questionnaire which developed by De Noble et al. (1999). The findings indicated that entrepreneurial self-efficacy among students were high. The result also inferred that defining core purpose and initiating investor relationships achieved showed the highest level, while, coping with unexpected challenges scored the lowest level. Schlaegel and Koenig (2014) who had carried out a meta-analysis and found a positive relationship between selfefficacy and entrepreneurial intention. Hence, based on the above reasoning, the following hypothesis were made:

Ha1: Attitude towards entrepreneurship is positively related to entrepreneurial intention Ha2: Entrepreneurial self-efficacy is positively related to entrepreneurial intention.

Ha3: Subjective norms is positively related to entrepreneurial intention.

\section{Objectives of the Study}

The objectives of the study are four-fold, namely to determine (a)the attitude of undergraduates towards entrepreneurship; (b) the level of entrepreneurial self-efficacy of the undergraduate students; (c) perception toward the subjective norms; (d) the relationship between attitude and self-efficacy on entrepreneurship intention.

\section{Methodology}

This study was based on conceptual framework that combines part of adapted model of Ajzen's (1991) social psychology theory of planned behaviour to understand entrepreneurial intention and its relationship with the predictor variables. It is descriptive in nature. It employed a survey method using cross sectional research design. A self-administered questionnaire was used together information from the respondents. 


\section{Instrumentation}

The instruments to measure entrepreneurial intention and self- efficacy was adapted from Mcstay (2008). The original version of the scales for intention was taken from Krueger and Carsrud (1993), Chen, Greene, and Crick (1998) and Davidsson (1995). On the other hand, the main authors for self-efficacy were from Chen et al. (1998) and Forbes (2005). Whilst, the instruments to measure attitude toward entrepreneurship was adapted from Duijn (2003). Nevertheless, the original authors were from Carayannis, Evans, \& Hanson, 2003), (Lüthje \& Franke, 2003); Krueger et al., 2000); Autio et al., 2001). In this study, entrepreneurial intention can be referred to individual intention to be self employed. It contains 5 items with a seven Likert scales, ranging from 1 (strongly disagree) to 7 (strongly agree). An example of the statement for this scale; "I am very interested in setting up my own business" suggests a strong interest toward self employment/business ownership". On the other hand, self-efficacy is referred as individual's belief of his/her capability in performing the roles and tasks of an entrepreneur. There are 16 items with a seven Likert scales, ranging from 1 (strongly disagree) to 7 (strongly agree) measuring entrepreneurial self-efficacy. Samples of the statements include' believe I can create ways to improve existing products for a new business', I believe I can successfully conduct market analysis related to starting a new business"; I believe I can tolerate unexpected changes in business conditions." Whilst, attitude towards entrepreneurship is defined as individual expectations and belief about entrepreneurial activities and outcomes. It contains 5 items with a seven Likert scales, ranging from 1 (strongly disagree) to 7 (strongly agree). An example of the statement include: "In business, it is preferable to be an entrepreneur, rather than a large firm employee"

\section{Reliability Analysis}

To determine the internal consistency reliability of the instruments, Cronbach's alpha test was conducted. Cronbach's alpha was analyzed for each variable as depicted in the following Table:1. The result showed that the Cronbach alpha value range from 0.789 to 0.979 indicating a high internal consistency reliability of the instruments.

\section{Table 1: reliability test}

\begin{tabular}{ll}
\hline Instruments & Cronbach's alpha value \\
\hline Entrepreneurial intention & 0.789 \\
Attitude toward entrepreneurship & 0.863 \\
Entrepreneurial self-efficacy & 0.979 \\
Subjective norms & 0.873 \\
\hline
\end{tabular}

\section{Respondents}

In this study, the accessible population consists of 380 final year undergraduate students who had undertaken various programs from the faculty of Education, UiTM, Puncak Alam. The respondent size of 191 was selected based on Krejcie and Morgan (1970) recommended table. Nevertheless, a total 179 responded the questionnaire and the response rate of $93.7 \%$ was considered excellent (Babbie, 1998) 


\section{Results}

\section{Respondents' Profile}

The finding revealed that out of 179 respondents, female students $(71.3 \%)$ outnumbered the male students (28.7\%). The data was collected based on the year 2016, that is, final year undergraduate students from the Faculty of Education. In term of their age, majority of them were aged between $24-25$ years old (49.4\%) and about $35.6 \%$ of them were aged between $22-23$ years old. On the other hand, only $2.8 \%$ were aged less than 21 years old. Pertaining to the questions whether the respondents' parents ever started their own businesses, the result showed that $45.5 \%$ of respondents said that their parents are having their own businesses. The finding depicted that, about $37.5 \%$ of the students stated that have some experienced working in their family business and interestingly, $46.1 \%$ said that they had positive experienced working in a family business. The data also revealed that majority of the respondents (79.7\%) said that they had role model involved in their own business.

1) Analysis on the attitude towards entrepreneurship among undergraduate students

Table 2: Attitude towards entrepreneurship among undergraduate students

\begin{tabular}{lcc}
\hline Attitude & Mean & Std deviation \\
\hline 1. In business, it is preferable to be an entrepreneur, & 4.9096 & 1.18838 \\
$\quad \begin{array}{l}\text { rather than a large firm employee } \\
\text { 2. It is more beneficial to society to have large }\end{array}$ & 4.5480 & 1.26096 \\
$\quad \begin{array}{l}\text { enterprises than small firms } \\
\text { 3. I would rather find a new company than be the }\end{array}$ & 4.4294 & 1.33435 \\
$\quad \begin{array}{l}\text { manager of an existing one } \\
\text { 4. Starting my own business sounds attractive to me }\end{array}$ & 5.2994 & 1.22736 \\
5. I personally consider entrepreneurship to be a highly & & \\
$\quad \begin{array}{l}\text { desirable career alternative for people with my } \\
\quad \text { professional and education background }\end{array}$ & 5.1751 & 1.20031 \\
6. Overall, I consider an entrepreneurship as a career. & 4.6954 & 1.42410 \\
\hline Average mean score & $\mathbf{4 . 8 5 4 8}$ & $\mathbf{0 . 9 8 7 7 2}$ \\
\hline
\end{tabular}

Mean indicators: low: (1.00 -3.00); Moderate: (3.01- 5.00) High: (5.01- 7.00)

Table 2 reports the mean and standard deviation scores of respondents for attitude towards entrepreneurship among undergraduate students from the faculty of Education. The mean scores for each item are arranged in descending order to rank them from high to the least expectations and belief about entrepreneurial activities and outcomes. The finding showed that the overall mean score for respondents' attitude toward entrepreneurship were moderately high. This is evident in item no 4 (respondent's attitude toward starting their own business sound attractive) and item no 5 (respondent's consider entrepreneurship to be a highly desirable career alternative for people with my professional and education background) have the highest mean score, i.e. $M=5.299, S D=1.227$ and $\mathrm{M}=5.175, \mathrm{SD}=1.200$, respectively. However, item 1 (In business, it is preferable to be an entrepreneur, rather than a large firm employee; item no 6 (Overall, I consider an entrepreneurship as a career) and item no 2 (It is more beneficial to society to have large enterprises than small firms) 
have moderate mean scores., where the mean scores showed $M=4.909, S D=1.188, M=4.695, S D=$ 1.424 and $M=4.5480, S D=1.2609$ respectively. The least mean score was item no 3 (I would rather found a new company than be the manager of an existing one) where mean score showed $M=4.429$, $\mathrm{SD}=1.3343$. This study suggests that the undergraduate students show favorable attitude towards entrepreneurship. In fact, the result indicated that the respondents perceived high expectations and belief about entrepreneurial activities and outcomes as shown in item 4 and item 5 . This finding supports the study done by Rudhumbu et al (2016).

2) Analysis on the level of entrepreneur self-efficacy among undergraduate students

Table 3: The levels of entrepreneur self-efficacy among undergraduate students

\begin{tabular}{|c|c|c|}
\hline Level & Frequency & Percentage \\
\hline Low & 15 & 8.3 \\
\hline Moderate & 88 & 48.6 \\
\hline High & 78 & 43.1 \\
\hline Total & 181 & 100 \\
\hline
\end{tabular}

Table 3 depicted the levels of entrepreneur self-efficacy among undergraduate students of the Faculty of Education, UiTM, Puncak Alam. The findings revealed that majority of them, that is, $48.6 \%$ (88) demonstrated moderate level of self-efficacy and 43,1\% (78) showed high entrepreneur self-efficacy. On the other hand, only $15 \%$ (8.3) of respondent showed low level of entrepreneur selfefficacy. Interestingly, the result also shows that the differences in term of percentage for high and moderate self-efficacy is seemed small. However, on the whole, the finding indicates that the respondents' belief of their capability in performing the roles and tasks of entrepreneur were moderate. Hence, students who perceived moderate level of entrepreneurial self-efficacy will tend to demonstrate moderate capability towards entrepreneurial intention as compare to students who demonstrate high entrepreneurial self-efficacy.

3) Analysis on the perceptions toward subjective norms among undergraduate students

Table 4: Perceptions toward subjective norms among undergraduate students

\begin{tabular}{|c|c|c|}
\hline Subjective norms & Mean & Std dev \\
\hline 1.My family and friends support me to start my own business & 5.011 & 1.393 \\
\hline 2. If I became an entrepreneur, my family would consider it to be & 5.056 & 1.237 \\
\hline $\begin{array}{l}\text { 3. If I became an entrepreneur, my close friends would consider } \\
\text { it to be }\end{array}$ & 5.056 & 1.237 \\
\hline Average mean score & 5.041 & 1.289 \\
\hline
\end{tabular}

Table 4 showed the distribution of mean scores for perceptions toward subjective norms among the undergraduate students. The finding revealed that the respondents' perception towards subjective norms were high, where the overall mean showed average score $(M=5.041, S D=1.289)$. The highest mean score in this dimension was item no 2 (If I became an entrepreneur, my family would consider it to be) where $\mathrm{M}=5.056, \mathrm{SD}=1.237$ and item no 3 (If I became an entrepreneur, my close friends would consider it to be) where $M=5.056, S D=1.237$. This is followed by the last item, 
i.e. item no 1 (My family and friends support me to start my own business) where $M=5.011, S D=$ 1.393). The study suggests that respondents' reference people such as family and friends would have the tendency to approve their decision to become entrepreneur. This finding supported the research done by Souitaris et al. (2007).

4) Analysis on the relationship between attitude toward entrepreneurship and self- efficacy on entrepreneur intention among undergraduate students

Table 5: Correlation Matrix Analysis of attitude toward entrepreneurship, subjective norms and self- efficacy on entrepreneur intention

\begin{tabular}{lllll}
\hline Variables & Se-I & ENT-ATT & ESE & SN \\
\hline SE-I & 1 & & & \\
ENT ATT & $0.665^{* *}$ & 1 & & \\
ESE & $0.677^{* *}$ & $0.811^{* *}$ & 1 & 1 \\
SN & $0.585^{* *}$ & $0.740^{* *}$ & $0.677^{* *}$ & \\
\hline
\end{tabular}

** Correlation is significant at $\mathrm{p}<0.005$

$\mathrm{SE}-\mathrm{I}=$ entrepreneur intention; ENT ATT= entrepreneur Attitude; ESE= entrepreneurial self efficacy; SN= subjective norms

The relationship between entrepreneurial attitude, subjective norms and self-efficacy on entrepreneur intention was examined using the Pearson product moment correlation as presented in the table 5. The result depicted that there was a positive and moderate relationship between attitude toward entrepreneurship where $r=0.665, p=0.000$, entrepreneurial self-efficacy where $r=0.677, p=0.00$ and subjective norms where $r=0.585, p=0.00$ on entrepreneur intention. The result of this study was consistent with the research done by Tsordia \& Papadimitriou (2015) and Naina et al (2017).

\section{Discussions and Conclusion}

The current study intends to examine the relationship of attitude toward entrepreneurship, subjective norms and self-efficacy on entrepreneurial intentions. Using the lens of planned behaviour model as suggested by Azjen (1991), the findings confirmed the relationships among those variables and thus, it is evident that there is a critical need to understand entrepreneurial intentions, particularly among graduate students. According Krueger and Carsrud (1993) entrepreneurial intention is dependent on attitude toward target behaviour. Hence, this will then be reflected one's beliefs and perceptions. They further elaborated that intention model helps to explain the impact of various antecedents on what and how organizational emergence.

According to Bandura (1977) high levels of entrepreneurial self-efficacy may be linked to intentions for an entrepreneurial career. Bandura (1977) further elaborated that self-efficacy is an important motivational construct that influences individual choices, goals, emotional reactions, effort, coping and persistence. Thus, these motivational factors become the antecedent of entrepreneurial intention. High level of entrepreneurial self- efficacy reflects a high level of entrepreneurial intention as well as ultimately influence entrepreneurial activity. According to Lindsay and Balan (2005) individual with high self efficacy could enhance business performance. They 
claimed that high entrepreneurial self-efficacy's effect on performance could reduce level of self doubt. In other word, individual with high self- efficacy will have lower level of self-doubts. Therefore, this could enhance entrepreneur to be actively engaged in entrepreneurial tasks, persistent in facing difficulty and confident in meeting challenges. Consequently, another important predictor of intention is the concept related attitude towards entrepreneurship. Hannan et al (2004) reported that attitudinal approach has been employed in many disciples including entrepreneurship education. Hence, favourable attitude toward entrepreneurship can increase the level of entrepreneurial initiative. The finding showed that there was a positive and moderate relationship between subjective norms and intentions. The presumption is that the more favourable the social norm towards entrepreneurship, the greater will be the intention to perform the behaviour. Besides, interesting evident showed about $45.5 \%$ of the respondents said that their parents are having their own businesses and in fact, they have some experienced working in their family business. This indicates that family and close friends of the respondents could exert influence about entrepreneurial activities. Hence, the positive reactions of the subjective norms could be resulted that the respondents' intent to make entrepreneurship as their career choice.

The present study has several practical implications for the deans, managers and educators in higher learning. Perhaps, in fostering entrepreneurial intention among graduates, the management could establish policies and practices that could enhance entrepreneurial activities. Firstly, the finding indicated that the respondents' attitude and entrepreneurial self-efficacy ranges from moderate to high. Hence, this finding reflects positive indicators that these future trainee teachers have tendency to venture themselves into entrepreneurship. Therefore, this imply that managers and educators need to consider various entrepreneurial educational programs and also encourage undergraduate students to participate in entrepreneurial activities. In this context, Norshidah et al (2015) suggested that the dean and educators particularly from the faculty of Education to design a quality entrepreneurship curriculum and infrastructure so that they could develop students' opportunity and identification capabilities. Besides, there is also a need to inculcate entrepreneurial culture among the students. More importantly, the teaching of entrepreneurship courses should be interesting and impactful to the students. It should not be merely done in the classroom context, but rather expose these students with experiential learning and also hands-on learning approaches. The learning process may involve start-up businesses, design-based learning and reflective practices. Secondly, universities need to provide support and avenue to those students by sending them for internship program or gain practical experiences in entrepreneurship. In addition, the university could stimulate entrepreneurial climate by setting up business incubators in or around university campuses. The involvement of local business leaders in incubators program is important as they not only can assist in funds but also provide advice on policy and financial matters. In sum, not all students will be entrepreneur, however, by exposing them into the 'real world of business' could eventually develop them to act entrepreneurial. Although the results are encouraging, the present study also has some limitations. This study only utilized cross sectional design, hence, in order to provide better insights and clarifications, it is recommended that future research could utilize mixed-method research which integrates qualitative and quantitative methods. It is also suggested that a longitudinal study can be employed. A longitudinal study would enable researchers to study the changes of respondents' behaviour or characteristics over time 


\section{References}

Ajzen, I. (1987). Attitudes, traits, and actions: Dispositional prediction of behavior in personality and social psychology. In L. Berkowitz (Ed.), Advances in experimental social psychology. New York: Academic Press.

Ajzen, I. (1991). Theory of Planned Behaviour. Organizational Behaviour and Human Decisions Processes, 50 (2), 179-211

Ajzen, I. (2002). Perceived behavioral control, self-efficacy, locus of control, and the theory of planned behavior. Journal of Applied Social Psychology, 32(4), 665-683.

Amouri, A., Sidrat, S., Boudabbous, S., \& Boujelbene, Y. (2016). Effects of role models on developing attitude towards entrepreneurship among graduate students in Tunisia. Journal of Business and Management, 18(7), 73-80.

Armitage, C. J., \& Conner, M. (2001). Efficacy of the theory of planned behavior: A meta analytic review. British Journal of Social Psychology, 40(4), 471-499.

Autio, E., Keeley, R. H., Klofsten, M., Parker, G. G. C., \& Hay, M. (2001). Entrepreneurial intent among students in Scandinavia and in the USA. Enterprise and Innovation Management Studies, 2(2), 145-160.

Bandura, A. (1997): Self-efficacy: The exercise of control. New York: Freeman, Henry Holt and company.

Bakar, H., Mohamad, A., Hashim, N., Keat, O. Y., \& Abdullah, S. (2012) Kajian Pengesanan Graduan Sarjana Muda Keusahawanan (SMK) 2012. Laporan Penyelidikan Geran LEADS. Kolej Perniagaan. Universiti Utara Malaysia

BarNir, A., Watson, W. E., \& Hutchins, H. M. (2011). Mediation and moderated mediation in the relationship among role models, self-efficacy, entrepreneurial career intention, and gender. Journal of Applied Social Psychology, 41, 270-297.

Basu, A., \& Virick, M. (2008). Assessing entrepreneurial intentions amongst students: A comparative study. Retrieved from http://works.bepress.com/anuradha_basu/12/

Bird, B. (1989) Implementing entrepreneurial ideas: the case of intension. Academic Management Review 13(3), 442-453.

Bliemel, M. (2014). Getting Entrepreneurship Education Out of the Classroom and Into Students' Heads Entrepreneurship Research Journal, 4(2), 237- 260

Boyd, N. G., \& Vozikis, G. S. (1994).The Influence of Self-efficacy on the Development of Entrepreneurial Intentions and Actions. Entrepreneurship Theory and Practice, 18(4), 63-77.

Buang, N. A. ( 2013). Pendidikan Keusahawanan. Bangi: Penerbit Universiti Kebangsaan Malaysia

Charney, A., \& Gary, L. (2000). The Impact of Entrepreneurship Education: An Evaluation of the Berger Entrepreneurship Program at the University of Arizona. Retrieved from file://C:/Users/USER/Downloads/SSRN-id1262343.pdf

Chen, C. C., Greene, P. G., Crick, A. (1998) Does entrepreneurial self-efficacy distinguishes entrepreneurs from managers? Journal of Small Business Venture. 13(4), 295-316.

DeNoble, A. F., Jung, D., \& Ehrlich, B. (1999). Entrepreneurial Self-Efficacy: The Development of a Measure and Its Relationship to Entrepreneurial Action. Babson College. retrieved from file://C:/Users/USER/Downloads/Evaluating_the_Role_of_Entrepreneurial_Self-Effica.pdf

Duijn, W. (2009). Entrepreneurial intention among FDEWB students. retrieved from http://www.studiosus.nl. 
Ediagbonya, K. (2013). The Roles of Entrepreneurship Education in Ensuring Economic Empowerment and Development. Journal of Business Administration and Education, 35-46.

Fishbein, M., \& Ajzen, I. (1975). Belief, attitude, intention and behavior: An introduction to theory and research. New York: Addison-Wesley.

Hannan, M., Hazlett, S. A., \& Leitch, C. ( 2004) . Entrepreneurship Education: How Do We Measure Success? Working paper, Queen's University Belfast.

Hisrich, R. D., and Peters, M. (2002) Entrepreneurship, McGraw-Hill Companies Incorporation.

Kamau-Maina, R. (2006) Structured Qualitative Methods, Stimulating Youth Entrepreneurship in Kenya. Concept Paper. 1-38.

Kumar, G. (2014). Understanding Institutions in the Context of Entrepreneurship. Journal of Entrepreneurship, Business and Economics, 2(2), 45-81

Krueger, N. F., Jr., Reilly, M. D., \& Carsrud, A. L. (2000). Competing models of entrepreneurial intentions. Journal of Business Venturing, 15(5-6), 411-432.

Krueger, N. F., \& Carsrud, A. L. (1993).Entrepreneurial intentions: Applying the Theory of Planned Behavior, Entrepreneurship and Regional Development. 5, 315-330.

Lame, M. S., \& Yusoff, W. F. (2013) The Perception of Students Towards Entrepreneurship Courses: An Empirical Study of Nigerian Polytechnics Students, Proceeding in 2nd International Conference on Technology Management, Business and Entrepreneurship.

Lindsay, N. J., and Balan, P. (2005). Entrepreneurial Self-Efficacy and Personal Entrepreneur Success. Paper presented at the 2nd AGSE International Entrepreneurship Research Exchange, Melbourne, Australia.

Linan, F. (2004). Intention-based models of entrepreneurship education. Small Business. (3), 11-35

Linan, F., \& Chen, Y.W. (2009) Development and Cross-Cultural Application of a Specific Instrument to Measure. Entrepreneurial intentions entrepreneurship theory and practice, 593-617. Retrieved from http://institucional.us.es/vie/documentos/resultados/LinanChen2009.pdf

Low, M., \& MacMillan, I. (1988). Entrepreneurship: Past Research and Future Challenges. Journal of Management. 14, 139-161.

Lüthje, C., \& Franke, N. (2003). The making\| of an entrepreneur: testing a model of entrepreneurial intent among engineering students at MIT. R\&D Management, 33(2), 135-147

McStay, D. (2008) An investigation of undergraduate student self-employment intention and the impact of entrepreneurship education and previous entrepreneurial experience. Unpublished doctoral degree dissertation. Australia, Bond University.

Mohamad, A., Buang, N. A., \& Hussin, M. (2014) Memformulasikan Pelajar Institusi Pengajian Tinggi Ke Arah Kerjaya Usahawan. Persidangan Kebangsaan Ekonomi Malaysia ke-9 "Urus Tadbir Ekonomi yang Adil : ke arah Ekonomi Berpendapatan Tinggi" Kuala Terengganu, Terengganu, 17 - 19 Oktober, 433 - 441

Naia, A., Baptista, R., Biscaia, R., Januário, C., \& Trigo, V. (2017) Entrepreneurial intentions of Sport Sciences students And Theory of Planned Behaviour. Motriz, Rio Carlo: Journal of Physical Education, 23(1).

Pihie, Z. A. L. (2009). Entrepreneurship as a career choice: an analysis of entrepreneurial selfefficacy and intentions of university students, European Journal of Social Sciences, 9(2), 338349.

Pihie, Z. A. L., \& Bagheri, A. (2011) Teachers' and Students' Entrepreneurial Self-efficacy: Implication for Effective Teaching Practices. Procedia - Social and Behavioural Sciences, 29, 1071 - 1080 
Pulka, B. M., Rikwentishe, R., \& Ibrhain, B. (2014). Evaluation of Students' Attitude towards entrepreneurship education in some selected universities in North East Nigeria. Global Journal of Management and Business Research, 14(8), 1-8.

Rahim, H. L., \& Mohtar, S. (2015). Social Entrepreneurship: A Different Perspective. International Academic Research Journal of Business and Technology. 1(1), 9-15

Rudhumbu, N., Svotwa, D., Munyanyiwa, T., \& Mutsau, M. (2016) Attitudes of students towards Entrepreneurship Education at Two Selected Higher Education Institutions in Botswana: A Critical Analysis and Reflection. Academic Journal of Interdisciplinary Studies, 5(2).

Schlaegel, C., \& Koenig, M. (2014). Determinants of Entrepreneurial Intent: A Meta-Analytic Test and Integration of Competing Models. Entrepreneurship Theory and Practice, 38, 291-332.

Setiawan, J. L. (2013). Examining Entrepreneurial Self-Efficacy among Students. The 5th Indonesia International Conference on Innovation, Entrepreneurship, and Small Business. Procedia Social and Behavioral Sciences. (115), 235-242.

Shane, S., Locke, E. A., \& Collins, C. J. (2003). Entrepreneurial motivation. Human Resource Management Review, 13, 257-279.

Shapero, A., \& Sokol, L. (1982): "Social dimensions of entrepreneurship", in Kent, C.A., Sexton, D.L. and Vesper, K.H. (Eds.) Encyclopedia of entrepreneurship. New Jersey: Prentice Hall, Englewood Cliffs.

Shook, C. L., Priem, R. L., \& McGee, J. E. (2003). Venture creation and the enterprising individual: A review and synthesis. Journal of Management, 29, 379-399.

Solesvik, M., Westhead, P., Kolvereid, L., and Matlay, H. (2012) Student intentions to become selfemployed: the Ukrainian context. Journal of Small Business and Enterprise Development, 19(3), 441-460.

Solomon, G., Duffy, S., and Tarabishy, A. (2002). The state of entrepreneurship education in the United States: A nationwide survey and analysis. International Journal of Entrepreneurship Education, 1(1), 65-86

Souitaris, V., Zerbinati, S. T., and Al-Laham, A. (2007) “Do entrepreneurship programs raise Entrepreneurial Intention of Science and Engineering students? The effect of learning, inspiration and resources", Journal of Business Venturing, 22, 566-591.

Tawil, M., Hassan, R., Ramlee, S., and Batcha, Z. K. (2014) Enhancing entrepreneurship skill among university's students by online business simulation. Journal of Engineering Science and Technology. Special Issue on 4th International Technical Conference, 71-80

Tkachev, A., \& Kolvereid, L. (1999). Self-employment intentions among Russian students. Entrepreneurship and Regional Development, 11(3), 269-280.

Tsordia, C., \& Papadimitriou, D (2015). The role of Planned Behaviour on Entrepreneurial intention of Greek Business students. International Journal of Synergy and Research. 4 (1)

Wilson, F., Kickul, J., \& Marlino, D. (2007). Gender, entrepreneurial self-efficacy, and entrepreneurial career intentions: Implications for entrepreneurship education. Entrepreneurship Theory and Practice, (32), 387-406.

$\mathrm{Wu}$, S., and Wu, L. (2008) The impact of higher education on entrepreneurial intentions of university students in China, Journal of Small Business and Enterprise Development, 15(4), 752-774.

Zhao, H., Seibert, S. E., \& Hills, G. E. (2005). The mediating role of self-efficacy in the development of entrepreneurial intentions. Journal of Applied Psychology, 90(6), 1265-1272. 